International Journal of Instruction e-ISSN: 1308-1470 • www.e-iji.net
July $2020 \bullet$ Vol.13, No.3

p-ISSN: 1694-609X

pp. 475-490

Received: 04/07/2019

Revision: 05/02/2020

Accepted: 10/02/2020

OnlineFirst:30/04/2020

\title{
Evaluation of the Teachers' Acceptance to E-Report Card Applications with the Hot-Fit Model Approach
}

\author{
Ketut Agustini
}

Universitas Pendidikan Ganesha, Indonesia, ketutagustini@undiksha.ac.id

I Gede Mahendra Darmawiguna

Universitas Pendidikan Ganesha, Indonesia, mahendra.darmawiguna@undiksha.ac.id

I Kadek Dwi Artayasa

Universitas Pendidikan Ganesha, Indonesia, kd.dwiartayasa@gmail.com

I Nengah Eka Mertayasa

Ganesha University of Education, Indonesia, eka.mertayasa@ undiksha.ac.id

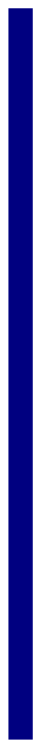

This study aimed at determining the factors that influence teacher acceptance of the application of the e-Report Junior High School application with the Human Organization Technology (HOT) Fit Model approach. The population in this study used all teacher in SMP Laboratorium Undiksha Singaraja and SMP 2 Singaraja amounted to 150 respondents. Sampling using proportional random sampling technique. The sample in this study amounted to 67 respondents. Primary data collection was obtained based on questionnaires to respondents. The Instrument of questionnaires was validited by content judges to get validity and reliable instrument. Data were analyzed using Structural Equation Model-Partial Least Square (SEM-PLS) with SmartPLS 3.0 software. The results of this study indicated that (1) System quality did not affect system usage, information quality did not affect system usage, and service quality had a positive effect on system usage of $36.7 \%$. (2) The quality of the system did not affect user satisfaction, the quality of information had a positive effect on user satisfaction by $50.6 \%$, and service quality did not affect user satisfaction. (3) User satisfaction had a positive effect on system usage by $15.4 \%$. (4) Organizational structure had a positive effect on system usage by $25.2 \%$. (5) The use of the system did not affect the net benefit, user satisfaction had a positive effect on the net benefit of $62.1 \%$, and the organizational structure did not affect the net benefit.

Keywords: junior high school e-report application, human, organization, technology, HOT fit model

Citation: Agustini, K., Darmawiguna, I. G. M., Artayasa, I. K. D., \& Mertayasa, I. N. E. (2020). Evaluation of the Teachers' Acceptance to E-Report Card Applications with the Hot-Fit Model

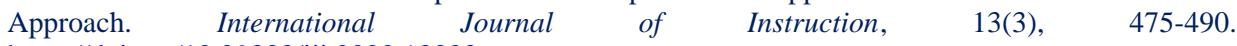
https://doi.org/10.29333/iji.2020.13333a 


\section{INTRODUCTION}

Reformation in the world of education is currently undergoing very significant changes along with the developments and the needs of human resources. One of them is curriculum change and innovation in the world of education. The curriculum is the most significant guide in the education process. The curriculum was developed with the aim of establishing a high-quality education system at the national and international level (Akınoğlu, 2019).

Indonesian Education has implemented the latest curriculum, namely 2013 Curriculum which has been implemented in stages starting in the 2013/2014 school year. Curriculum changes provide an innovation in the implementation of learning and assessment to achieve competency in attitudes, knowledge, and adequate skills for students (Nurdyansyah \& Fahyuni, 2016).

The process of evaluating student learning outcomes, both by educators and by educational units, will be more systematic, comprehensive, more accurate, and faster to do when supported by computer application devices. In this regard, the Directorate of Junior High School Development, Directorate General of Primary and Secondary Education, Ministry of Education and Culture, released the e-Report application for JUNIOR HIGH SCHOOL which was integrated with national education main data.

The implementation of the application of the e-Report application has not only run in one or two schools, but has been implemented gradually in all regions of Indonesia since the release of the e-Report application. As one of the regions in Indonesia, the city of Singaraja as an education center in North Bali has implemented the e-Report application at the junior high school level from the 2017/2018 school year. E-Report application is developed to facilitate teachers as educators in designing, implementing, processing, reporting, and utilizing the results of the assessment properly.

Even though it is mandatory, in its implementation, the e-Report application has not fully been able to run as expected, there are still some obstacles found at the level of acceptance of e-Report application users (Nurani, et al 2015).

In contrast, from the user factor, teachers, experiencing difficulties and feeling burdened when using the e-Report application because of the lack of understanding and skills of the teachers in using the e-Report application especially for teachers who are already senior and were not used to operate computers (Nurani, et al 2015).. The name of the student in the e-Report application does not match the order in the manual absence used by the teacher, so it does not rule out the possibility of inputting the student's value in the e-Report application because the teacher lacks in synchronizing the student value data causing invalid student data not relevant to the results obtained. The result of this problem is that the application of the e-Report application is not well targeted and will have an impact on the quality of the information produced.

The constraints of organizational factors are the lack of even training in the use of the eReport application provided. There is no policy from the school such as sanctions given to teachers who do not use the e-Report application. This results in a lack of 
understanding of the user and a reduction in teacher interest in using the e-Report application.

The obstacle of the technology factor is that the e-Report application web page will be difficult to access if it is opened simultaneously, especially nearing the printing report card period. The e-Report application can only be used on computers connected on one server and has been installed e-Report application, so that most teachers work offline by downloading the rating format on the e-Report application and when it is finished filling the data will be imported again on the e-Report application. The limited hardware such as the number of computers available does not meet the capacity of the teacher as the eReport application user. This has an impact on user satisfaction in using the e-Report application. E-report makes it easy for users to work. Gather data, manage data and organize school data.

In addition, the e-Report application is relatively new and has never been evaluated on the receipt of the e-Report application. The success of the application of information systems is not only determined by how the system can obtain input and produce information well, but also how users want to receive and use it, so as to achieve organizational goals. To be able to know the performance of information system implementation, evaluation is needed.

Evaluation is one of the important aspects needed to determine the success of the implementation of an information system (Yuliasari, 2014). Through evaluation, information will be obtained about the extent to which the achievement of the objectives of the system is successful and there would also the feedback to improve the quality of the system in the future. There are three important components that can influence the application of an information system, namely human, organizational and technological components. Users or humans need to be evaluated because humans as users (users) are directly related to the system. Organizations need to be evaluated because the introduction of new technologies can change services, operations, and organizational structures. Technology needs to be evaluated because it is part of the system.

The application of a technology is not only based on internal factors of the user but is also influenced by external factors such as humans and organizations (Yusuf, 2016). The success of the application of information technology must be measured comprehensively by including the involvement of the organization in the use of information technology by users. The measurement model that is able to accommodate three important components that can influence the application of an information system, namely the human component, organization, and technology that influences the usefulness, namely by using the HOT Fit Model approach (Maryati \& Yusof, 2018).

Based on the importance of e-report implementation to improve school performance described above, the authors conducted a study that linked teacher acceptance of the eReport application by referring to the framework of the HOT-Fit Model. This model was chosen because this model is complete from the aspect of assessment and in accordance with existing problems. It is expected that this study can provide empirical evidence regarding factors that influence teacher acceptance of the application of e- 
Report applications so that they can be used as a reflection material in increasing the use of e-Report applications optimally.

\section{LITERATURE REVIEW}

\section{Evaluation}

Evaluation is an activity to gather information about the workings of something, which is then used to determine the right alternative in making decisions. The main function of evaluation in this case is to provide information that is useful for the decision maker to determine policies that will be taken based on evaluations that have been carried out (Arikunto, 2002). Acceptance of information systems can be measured by several evaluation models that have been developed at this time. One evaluation model that can be used in evaluating information systems is the human organization technology (HOT) Fit Model.

\section{Middle School e-Report Card Application}

e-Report in SMP is a web-based application/software that functions for management assessment and compiling student competency outcomes (report cards) in education units at the junior high school level.

\section{Human, Organization, Technology (HOT) Fit Model}

The HOT-Fit theory is revealed Yusof et al., (2006) at the 39th International Hawaii Sciences System conference. The framework of HOT Fit model is the development of the success information system model of DeLone and McLean by placing important components in the evaluation of information systems namely human, organization, and technology and the suitability of the relationships presented in Figure 1.

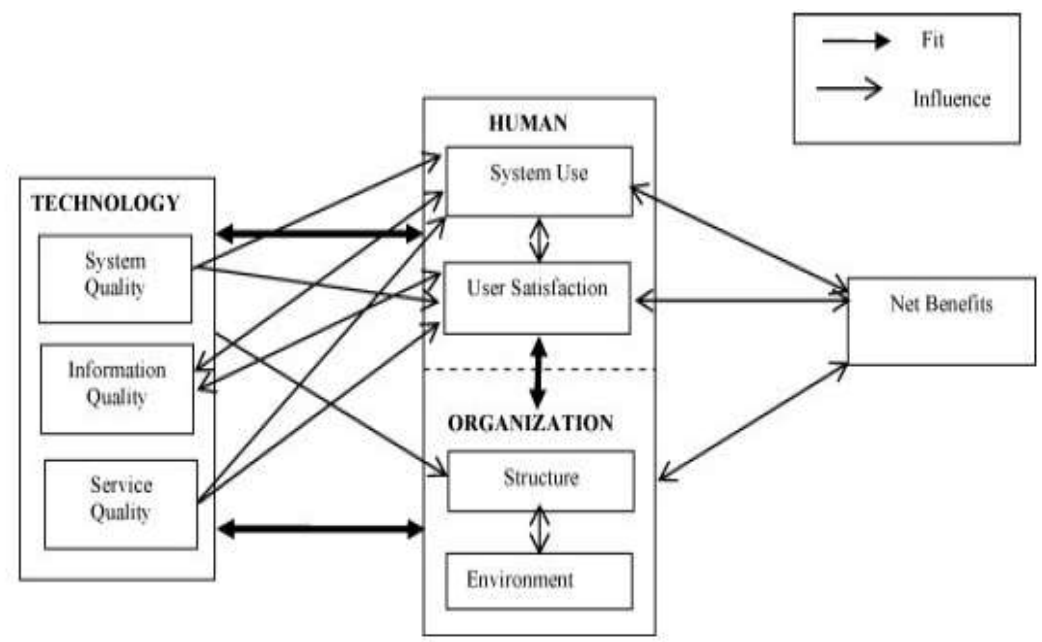

Figure 1

Human-Organization-Technology (HOT) Fit Model (Source:Yusof et al., 2006) 
The theoretical framework of evaluation using HOT Fit models is as follows:

\section{Human components (Human)}

Human components (human) assess information systems in terms of system use (system use) on the frequency and extent of functions and information system investigations. System use also relates to who uses (who use it), the level of users (level of user), training, knowledge, expectations and attitudes of acceptance or rejecting the system (Maryati \& Yusof, 2018).. This component also assesses the system from the aspect of user satisfaction. User satisfaction is the overall evaluation of user experience in using information systems and the potential impact of information systems. User satisfaction can be associated with the perception of usefulness and user attitudes towards information systems that are influenced by personal characteristics.

\section{Organizational components (Organization)}

The organizational component assesses the system from the organizational structure and organizational aspects. The organizational structure consists of types, culture, politics, hierarchy, system planning and control, strategy, management and communication (Maryati \& Yusof, 2018). Leadership, support from top management and staff support are important parts of measuring system success. Whereas the organizational environment consists of funding sources, government, politics, competition, interorganizational relations and communication.

\section{Components of technology (Technology)}

The technology component consists of system quality, information quality and service quality (Maryati \& Yusof, 2018). The quality of the system in information systems concerns the interrelation of features in the system including system performance and user interface. Ease of use (ease of use), ease of learning (ease of learning), response time, usefulness, availability, flexibility, and securities are variables or factors that can be assessed from the quality of the system. Quality information focuses on information generated by information systems. Criteria that can be used to assess the quality of information include completeness, accuracy, timeliness, availability, relevance, consistency, and data entry. While service quality focuses on the overall support received by system service providers or technology. Service quality can be assessed by the speed of response, assurance, empathy and follow-up service.

\section{Net benefit}

Net benefit is a balance between the positive and negative effects of users of information systems (Maryati \& Yusof, 2018). Net benefits can be accessed using direct benefits, job effects, efficiency and effectiveness, reducing error rates, controlling expenses and costs. The more positive of user satisfaction outcome then the implementation of information system is more successful. 


\section{METHOD}

\section{Sample}

The samples taken were 67 respondents using the e-Report application, namely subject teachers distributed at the SMP Laboratorium Undiksha Singaraja and SMP 2 Singaraja. In choosing a sample, researchers used a proportional random sampling technique at a $5 \%$ significance level.

\section{Research Design}

This research was carried out using a survey approach, which is a research that takes samples from a population and uses a questionnaire as a tool for collecting data. The data collected use to evaluate teachers' acceptance Survey research conducted is an explanation (exploratori), which explains the causal relationship between variables through hypothesis. Qualitative data was obtained through interviews with operators and some subject teachers as e-Report application users. Qualitative data collected to get information about experience when using e-Raport application. While quantitative data was obtained from the results of distributing questionnaires to subject teachers as users of the e-Report application. Quantitative data collected to get e-Report users responses.

\section{Instrument}

The instrument in this study was a questionnaire. The questionnaire lists statements from Human variables consisting of system usage and user satisfaction, Organization variables consisting of organizational structure, Technology variables consisting of system quality, information quality, and service quality, and Net benefit variables. The type of questionnaire was closed, which means that the respondent must choose one of the answers that are available. The measurement scale used in this questionnaire uses a Likert scale using a range of scores 1-5. After the questionnaire has been compiled, it will be tested to be used to obtain research data.

\section{Data Collection and Data Analysis}

Primary data collection was obtained from the results of questionnaires to e-Report application users as research respondents. While secondary data was obtained from the literature review of books, journals, articles, and other literature that are relevant to the research topic. Secondary data is used as a result of data findings in primary data.

Data analysis in this study was using Structural Equation Model-Partial Least Square (SEM-PLS) with SmartPLS 3.0 software which started from the analysis of the measurement model (outer model), structural model analysis (inner model), and hypothesis testing. PLS (partial least square) is a variant-based structural equation (SEM) analysis that can simultaneously test measurement models while testing structural models (Giyanti \& Indriastiningsih, 2019). The measurement model was used to test validity and reliability of instrument to collect responden data, while the structural model was used to test causality (testing hypotheses with prediction models). Causality test used to compare data from any variable obtained from a user's response 


\section{Measurement Model}

The measurement model or outer model illustrates the relationship between indicator blocks and latent variables. There are three criteria for evaluating the outer model, namely convergent validity, discriminant validity or using variant extraction average, construct reliability measured using cronbach's alpha and composite reliability (Purnomo, 2017).

In Smart-PLS, convergent validity is the same as the outer loading / loading factor that describes the magnitude of the correlation between each item measuring indicators with other variables. The ideal value for declaring an indicator that is valid is greater than 0.7 (Santosa, 2018). The results of loading factors can be seen in Figure 2.

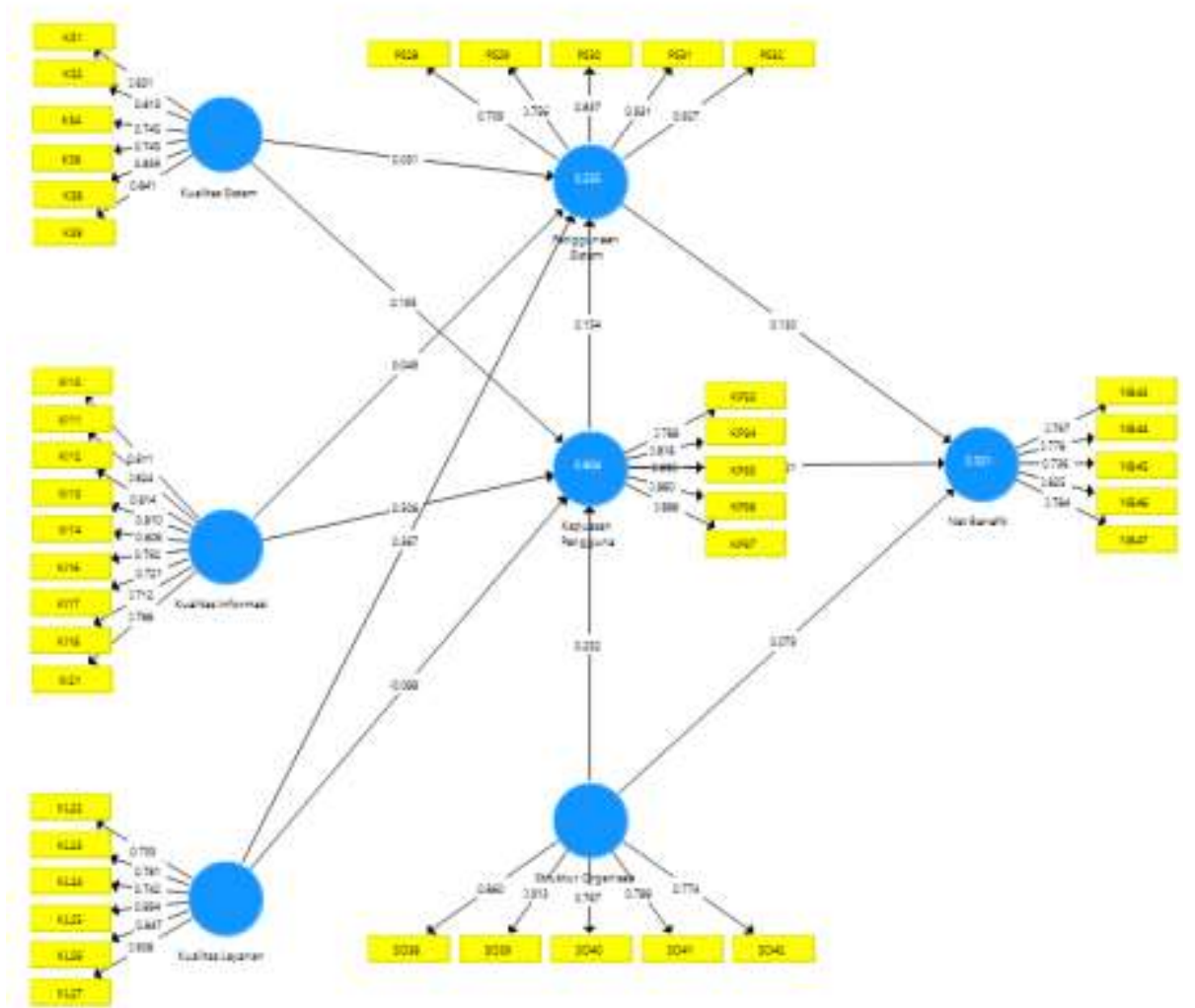

Figure 2

Results of the Loading Factor

Based on the results of interest in Figure 2, it shows that all indicators have a loading factor value above 0.7 , so that all indicators meet converging validity and have good validity (Purnomo, 2017). 
Discriminant validity aims to test that a measuring instrument precisely measures the measured construct, not another construct.

Table 1

AVE values and Root AVE

\begin{tabular}{lcl}
\hline Variable & AVE & Root AVE \\
\hline User Satisfaction & 0,707 & 0,841 \\
\hline Information Quality & 0,620 & 0,787 \\
\hline Service Quality & 0,678 & 0,823 \\
\hline System Quality & 0,651 & 0,807 \\
\hline Net Benefit & 0,616 & 0,785 \\
\hline System Usage & 0,700 & 0,837 \\
\hline Organizational structure & 0,676 & 0,822 \\
\hline
\end{tabular}

Based on table 1, it can be seen that the average variance extracted for all variables above 0.5 , so that it can be said that all variables are valid (Purnomo, 2017).

Test reliability in SmartPLS is measured by two criteria, namely cronbach's alpha and composite reliability. The rule of thumb cronbach's value and composite reliability must be greater than 0.7 (Abdillah \& Hartono, 2015).

Table 2

Cronbach's Alpha and Composite Reliability values

\begin{tabular}{lcl}
\hline Variable & Cronbach's Alpha & Composite Reliability \\
\hline User Satisfaction & 0,896 & 0,923 \\
\hline Information Quality & 0,923 & 0,936 \\
\hline Service Quality & 0,905 & 0,926 \\
\hline System Quality & 0,892 & 0,918 \\
\hline Net Benefit & 0,845 & 0,889 \\
\hline System Usage & 0,891 & 0,920 \\
\hline Organizational structure & 0,879 & 0,912 \\
\hline
\end{tabular}

Based on table 2, it can be seen that the cronbach's alpha and composite reliability values is greater than or equal to standard error 0,05 on the model meet the reliability requirements.

\section{FINDINGS}

\section{Structural Model}

The structural model or inner model aims to evaluate the relationship between latent constructs as hypothesized. The structural model in PLS was evaluated by using the coefficient of determination or R-Square for endogenous constructs, the value of the path or t-value coefficients for each path for the interconstructive significance test in the structural model.

The path coefficient value showed the inter-variable relations stated in the hypothesis. The significance level of a path coefficient value was obtained by the bootstrap procedure so that it produced a t-statistics value that will be compared with the t-table value. The results of path coefficients and values can be seen in table 3 . 
Table 3

Path Coefficient

\begin{tabular}{lcl}
\hline Path Chart & Path Coefficient $(\boldsymbol{\beta})$ & t-statistics Value \\
\hline System Quality $\rightarrow$ System Usage & 0,031 & 0,175 \\
\hline System Quality $\rightarrow$ User satisfaction & 0,195 & 1,574 \\
\hline Information Quality $\rightarrow$ Use of the System & 0,049 & 0,289 \\
\hline Information Quality $\rightarrow$ User Satisfaction & 0,506 & 4,142 \\
\hline Quality of Service $\rightarrow$ Use of the System & 0,367 & 3,109 \\
\hline Quality of Service $\rightarrow$ User Satisfaction & $-0,088$ & 0,741 \\
\hline User Satisfaction $\rightarrow$ System Usage & 0,154 & 1,844 \\
\hline Organizational Structure $\rightarrow$ User Satisfaction & 0,252 & 1,683 \\
\hline Use of the System $\rightarrow$ Net Benefit & 0,130 & 1,217 \\
\hline User Satisfaction $\rightarrow$ Net Benefit & 0,621 & 4,295 \\
\hline Organizational Structure $\rightarrow$ Net Benefit & 0,079 & 0,493 \\
\hline
\end{tabular}

Based on Table 3, it can be seen that the significance of the influence between variables by looking at the value of the parameter coefficient and the significance value of the $t$ statistic.

Testing of the structural model is done by looking at the R-Square value which is a goodness-fit model test. The results of the analysis of R-Square values are shown in table 4 .

Table 4

Value of R-Square

\begin{tabular}{lc}
\hline Variable & R-Square \\
\hline System Usage & 0,235 \\
\hline User Satisfaction & 0,604 \\
\hline Net Benefit & 0,521 \\
\hline
\end{tabular}

Based on the R-Square value obtained in accordance with table 4, it shows that the system usage construct has an R-square value of 0.235 , which means that the variance in the system usage construct can be explained by the construct of system quality, information quality, service quality and user satisfaction by $23,5 \%$. While the other $76.5 \%$ is explained by other variables outside the model. The construct of user satisfaction has an R-square value of 0.604 which means that the variance in the construct of user satisfaction can be explained by the constructs of system quality, information quality, service quality and organizational structure by $60.4 \%$. While the other $39.6 \%$ is explained by other variables outside the model. The net benefit construct has a R-square value of 0.521 which means that the variance in the net benefit construct can be explained by the construct of system usage, user satisfaction, and organizational structure by $52.1 \%$. While the other $47.9 \%$ is explained by other variables outside the model.

Hypothesis testing was done by the T-statistic test to test the relationship whether the independent variables (exogenous) partially have a significant effect or not on the dependent variable (endogenous). 
In testing hypotheses, the level of significance used is $95 \%(\alpha=0,05)$. The value with a $95 \%$ confidence level (one-tailed) is 1.64 . The results of hypothesis testing can be seen in table 5.

Table 5

Hypothesis Testing Results

\begin{tabular}{lllll}
\hline Path Chart & Path Coefficients & $\begin{array}{l}\text { T Statistic } \\
(\mid \mathrm{O} / \mathrm{STDEV})\end{array}$ & P Values & $\begin{array}{l}\text { Test result } \\
(\alpha=0,05)\end{array}$ \\
\hline $\begin{array}{l}\text { System Quality } \rightarrow \text { System } \\
\text { Usage }\end{array}$ & 0,031 & 0,175 & 0,431 & Rejected \\
\hline $\begin{array}{l}\text { System quality } \rightarrow \text { User } \\
\text { satisfaction }\end{array}$ & 0,195 & 1,574 & 0,058 & Rejected \\
\hline $\begin{array}{l}\text { Information Quality } \rightarrow \\
\text { Use of the System }\end{array}$ & 0,049 & 0,289 & 0,386 & Rejected \\
\hline $\begin{array}{l}\text { Information Quality } \rightarrow \\
\text { User Satisfaction }\end{array}$ & 0,506 & 4,142 & 0,000 & Accepted \\
\hline $\begin{array}{l}\text { Quality of Service } \rightarrow \text { Use } \\
\text { of the System }\end{array}$ & 0,367 & 3,109 & 0,001 & Accepted \\
\hline $\begin{array}{l}\text { Quality of Service } \rightarrow \\
\text { User Satisfaction }\end{array}$ & $-0,088$ & 0,741 & 0,229 & Rejected \\
\hline $\begin{array}{l}\text { User Satisfaction } \rightarrow \\
\text { System Usage }\end{array}$ & 0,154 & 1,844 & 0,033 & Accepted \\
\hline $\begin{array}{l}\text { Organizational Structure } \\
\text { User Satisfaction }\end{array}$ & 0,252 & 1,683 & 0,047 & Accepted \\
\hline $\begin{array}{l}\text { Use of the System } \rightarrow \text { Net } \\
\text { Benefit }\end{array}$ & 0,130 & 1,217 & 0,112 & Rejected \\
\hline $\begin{array}{l}\text { User Satisfaction } \rightarrow \text { Net } \\
\text { Benefit }\end{array}$ & 0,621 & 0,295 & Accepted \\
\hline $\begin{array}{l}\text { Organizational Structure } \\
\rightarrow \text { Net Benefit }\end{array}$ & 0,079 & 0,493 & 0,311 & Rejected \\
\hline
\end{tabular}

From table 5, it can be seen that the hypothesis is accepted or rejected by looking at the value of $\mathrm{T}$ statistics and its path coefficient. If the value is higher than the value, then the hypothesis is supported or accepted, and vice versa.

\section{DISCUSSION}

\section{The Effect of System Quality on System Usage}

Based on the results of hypothesis testing, the value for the system quality variable on system use is 0.175 . This value was smaller than the value at the $95 \%$ confidence level of 1.64. This showed that there is no significant effect of system quality variables on system usage, therefore it can be stated that the first hypothesis (H1) is rejected. While the value coefficient of 0.031 proves that there is a very weak correlation between the quality of the system and the use of the system.

The results of this study are in line with those conducted by Arifin \& Pratolo, (2012) which shows that system quality does not have a significant positive effect on system 
usage. This is because the system is still simple and does not need the specifications of the device with good quality.

\section{Effect of System Quality on User Satisfaction}

Based on the results of hypothesis testing, the value for the system quality variable is obtained towards user satisfaction of 1.574. This value is smaller than the value at the $95 \%$ confidence level of 1.64 . This shows that there is no significant effect of system quality variables on user satisfaction, because it can be stated that the second hypothesis $(\mathrm{H} 2)$ is rejected. While the path coefficient of 0.195 proves that there is a positive correlation between system quality and user satisfaction.

The results of the hypothesis in this study have similarities with the research conducted by Maryana et al., (2018) which shows that the system quality variable does not affect user satisfaction. Research by Radityo, (2007) also states that system quality does not significantly influence user satisfaction. This is due to simple system display and simple menu offerings to make it easier for users.

\section{Effect of Information Quality on System Usage}

Based on the results of testing the hypothesis, obtained the value for the variable quality of information on system usage of 0.289 This value is smaller than the value at the $95 \%$ confidence level of 1.64. This shows that there is no significant effect of information quality variables on system usage, because it can be stated that the third hypothesis (H3) is rejected. While the value coefficient of 0.049 proves that there is a very weak correlation between the quality of information and the use of the system.

The results of this study are consistent with the research conducted by Betri et al., (2017) which states that the quality of information does not affect the use of the system. Research by Kodarisman \& Nugroho, (2013) shows that there is no significant effect of information quality variables on system usage. The same thing was also found in the study of Arifin \& Pratolo, (2012) which showed that the quality of information did not have a significant positive effect on system usage. This is because in the system only public information is available, and no information is too specific and strictly confidential.

\section{Effect of Information Quality on User Satisfaction}

Based on the results of testing the hypothesis, obtained the value for the variable quality of information on user satisfaction of 4.142. This value is greater than the value at the $95 \%$ confidence level of 1.64 . This shows that there is a significant effect of information quality variables on user satisfaction, therefore it can be stated that the fourth hypothesis (H4) is accepted. While the path coefficient of 0.506 proves that there is a positive correlation between the quality of information and user satisfaction.

This is in line with the opinion of Yusof et al., (2006) which states that information quality is the most influential factor on user satisfaction. The higher or better the quality of information, the higher the level of satisfaction with the system felt by the user. 
The results of the hypothesis in this study prove the same results in the study conducted by Maryana et al., (2018) which shows that the quality of information affects user satisfaction. The results of this study are also supported by Krisbiantoro et al., (2015) which states that there is a positive influence between the quality of information on user satisfaction. This is because in the system only public information is available, and no information is too specific and strictly confidential.

\section{Effect of Service Quality on System Usage}

Based on the results of testing the hypothesis, obtained the value for the variable quality of service to system usage of 3,109 . This value is greater than the value at the $95 \%$ confidence level of 1.64. This shows that there is a significant effect of service quality variables on system usage, therefore it can be stated that the fifth hypothesis (H5) is accepted. While the path coefficient is 0.367 , proving that there is a positive correlation between service quality and system usage.

The results of this study are consistent with previous research conducted by Monalisa et al., (2018) which shows that there is a significant influence between service quality on system usage. The results of this study are also in line with the research by Krisbiantoro et al., (2015) which states that there is a positive influence between service quality on system usage. The same thing is also obtained from the research of Kodarisman \& Nugroho, (2013) which shows that there is a significant influence of service quality variables on system usage. This is because on the system not too many services used, only input and data processing.

\section{Effect of Service Quality on User Satisfaction}

Based on the results of testing the hypothesis, obtained the value for the variable quality of service to user satisfaction of 0.741 . This value is smaller than the value at the $95 \%$ confidence level of 1.64. This shows that there is no significant effect of service quality variables on user satisfaction, because it can be stated that the sixth hypothesis (H6) is rejected. While the path coefficient value of -0.088 proves that there is a negative correlation between service quality and user satisfaction.

The results of the hypothesis in this study are in line with the research conducted by Monalisa et al., (2018) which shows that there is no significant influence between service quality and user satisfaction. This is because on the system not too many services used, only input and data processing.

\section{Effect of User Satisfaction on System Usage}

Based on the results of hypothesis testing, the value for the variable user satisfaction for system usage is 1.844 . This value is greater than the value at the $95 \%$ confidence level of 1.64. This shows that there is a significant effect of the variable user satisfaction on the use of the system, therefore it can be stated that the seventh hypothesis $(\mathrm{H} 7)$ is accepted. While the path coefficient is 0.154 , proving that there is a positive correlation between user satisfaction and system usage. 
The results of the hypothesis in this study prove the same results in a study conducted by Betri et al., (2017) which states that user satisfaction affects the use of the system. Research by Krisbiantoro et al., (2015) also states that there is a positive influence between user satisfaction and system usage. The same thing was also obtained from the research of Kodarisman \& Nugroho, (2013) which showed that there was a significant effect of the variable user satisfaction on system usage. Hal ini dikarenakan pengguaan sistem yang mudah digunakan dan tampilan yang sederhana.

\section{Effect of Organizational Structure on User Satisfaction}

Based on the results of hypothesis testing, the value of the organizational structure variable is obtained for user satisfaction of 1.683. This value is greater than the value at the $95 \%$ confidence level of 1.64. This shows that there is a significant effect of organizational structure variables on user satisfaction, because it can be stated that the eighth hypothesis (H8) is accepted. While the path coefficient is 0.252 , proving that there is a positive correlation between organizational structure and user satisfaction.

The results of the hypothesis in this study are consistent with previous research conducted by Monalisa et al., (2018) which shows that there is a significant influence between organizational structure on user satisfaction. This is because a good organizational structure in a system can make it easier to understand system workflows.

\section{The Effect of Using the System on Net Benefit}

Based on the results of hypothesis testing, the value of the system usage variable is obtained for the net benefit of 1,217. This value is smaller than the value at the $95 \%$ confidence level of 1.64. This shows that there is no significant effect of the system usage variable on the net benefit, because it can be stated that the ninth hypothesis (H9) is rejected. While the path coefficient worth 0.130 proves that there is a very weak correlation between the use of the system and the net benefit.

The results of this study have similarities with the research conducted by Kodarisman \& Nugroho, (2013) which shows that there is no significant effect of the system usage variable on the net benefit. This is because the system used is national standard so that it must be deployed in use.

\section{Effect of User Satisfaction on Net Benefit}

Based on the results of testing the hypothesis, obtained the value for the variable user satisfaction on the net benefit of 4,295. This value is greater than the value at the $95 \%$ confidence level of 1.64. This shows that there is a significant effect of the variable user satisfaction on the net benefit, because it can be stated that the tenth hypothesis (H10) is accepted. While the path coefficient is worth 0.621 proving that there is a positive correlation between user satisfaction and net benefits.

The results of this study prove the same results in a study conducted by Abda et al., (2018) which states that there is a direct (positive) relationship between user satisfaction and net benefits. Research by Krisbiantoro et al., (2015) also states that there is a positive influence between net benefit. The same thing was also obtained from the 
research of Kodarisman \& Nugroho, (2013) which showed that there was a significant effect of the variable user satisfaction on the net benefit. This is because the system used is uniform and easy to use so that user satisfaction increases.

\section{Effect of Organizational Structure on Net Benefit}

Based on the results of testing the hypothesis, the value for the organizational structure variable on the net benefit is 0.493 . This value is smaller than the value at the $95 \%$ confidence level of 1.64. This shows that there is no significant effect of organizational structure variables on net benefits, because it can be stated that the eleventh hypothesis (H11) is rejected. While the path coefficient is 0.079 , proving that there is a very weak correlation between organizational structure and net benefit.

Based on the results of the research, organizational support is a weak predictor of the net benefits of the e-Report application. Therefore, motivation is needed to encourage teachers to complete their tasks so that organizational effectiveness can be achieved. Papilaya et al., (2019) states that motivation has the power to determine the attitude of employees in the workplace. An employee who is highly motivated will be able to do the job effectively and efficiently and certainly has better performance. The results of this study are in accordance with the research of Soraya et al., (2019) which states that the organization has no influence on the net benefit. This is because it can not manage the system organization independently, because the system is uniform.

\section{CONCLUSION}

Based on the results of analysis and discussion, it can be concluded as follows (1) System quality does not affect the use of e-Report application, the quality of information does not affect the use of e-Report application and service quality has a positive effect on the use of e-Report application of $367 \%$. (2) The quality of the system does not affect the satisfaction of e-Report application users, information quality has a positive effect on e-Report application user satisfaction by $50.6 \%$, and service quality does not affect the satisfaction of e-Report application users. (3) User satisfaction has a positive effect on the use of e-Report application by $15.4 \%$. (4) The organizational structure has a positive effect on the use of the e-Report application at $25.2 \%$. (5) The use of the system does not affect the net benefit of the e-Report application, user satisfaction has a positive effect on the net benefit of the e-Report application at $62.1 \%$, and the organizational structure has no effect on the net benefit of the e-Report application. The implications of this research are as a matter of consideration and improvement in the development and use of e-report for the users.

Based on the results of the research that has been conducted, the researcher tries to give suggestions that can be useful for further research: (1) This study is only based on the perceptions of respondents, therefore the results obtained are highly dependent on the respondents' understanding of the statement items contained in questionnaire and also the seriousness of the respondent in filling out each statement. In further research, it is recommended to use better research instruments so that respondents have the obligation and responsibility to provide actual research data. It is also suggested to use qualitative analysis techniques or mixed methods to obtain a comprehensive analysis of research 
problems. (2) For further research, it is necessary to take into account the work culture variables and organizational environment that affect the use of the system or other more relevant variables so that the results of the research are expected to be close to the actual situation.

\section{REFERENCES}

Abda, P. D., Winarno, W. W., \& Henderi. (2018). Evaluasi Penerapan SIMRS Menggunakan Metode Hot-Fit di RSUD Dr. Soedirman Kebumen. INTENSIF, 2(1), 4656.

Abdillah, W., \& Hartono, J. (2015). Partial least square (PLS) alternatif structural equation modeling (SEM) dalam Penelitian Bisnis. Yogyakarta: Penerbit ANDI.

Akınoğlu, O. (2019). The meaning and context of curriculum. International Journal of Instruction, 12(3), i-iii.

Arifin, J. F., \& Pratolo, S. (2012). Pengaruh Kualitas Sistem Informasi Keuangan Daerah Terhadap Kepuasan Aparatur Pemerintah Daerah Menggunakan Model DeLone dan McLean. Jurnal Akuntansi \& Investasi, 13(1), 28-34.

Arikunto. (2002). Metodologi Penelitian. Jakarta: PT. Rineka Cipta.

Betri, T. J., Utami, E., \& Fatta, H. Al. (2017). Perancangan Arsitektur Aplikasi Learning Management System di Universitas Slamet Riyadi. Indonesia Journal of Applied Informatics, 2(1), 1-16.

Giyanti, I., \& Indriastiningsih, E. (2019). The effect of SME food entrepreneurs' understanding on halal certification on certification awareness using partial least square. Jurnal Teknik Industri, 20(2), 1-10.

Kodarisman, R., \& Nugroho, E. (2013). Evaluasi Penerapan Sistem Informasi Manajemen Kepegawaian (SIMPEG) di Pemerintah Kota Bogor. JNTETI, 2(2), 24-32.

Krisbiantoro, D., Suyanto, M., \& Taufiqluthfi, E. (2015). Evaluasi Keberhasilan Implementasi Sistem Informasi dengan Pendekatan HOT Fit Model (Studi Kasus: Perpustakaan STMIK AMIKOM Purwokerto). In Konferensi Nasional Sistem \& Informatika (pp. 896-901).

Maryana, F., Ridhawati, R., \& Sayekti, T. A. (2018). Pengaruh Kualitas Sistem dan Kualitas Informasi Terhadap Kepuasan Pengguna Aplikasi Pelayanan Pelanggan Terpusat (AP2T) PT PLN (Persero) Wilayah Kalimantan Tengah dan Kalimantan Selatan Area Barabai, 11(2), 213-229.

Maryati, M., \& Yusof, A. (2018). An evaluation framework for health information systems: Human, organization and technology-fit factors (HOT-fit). International Journal of Medical Informatics,, 77(6), 377-385. https://doi.org/10.1016/j.ijmedinf. 2007.08.011, access Novemer 10, 2019.

Monalisa, S., Anggara, P. P., \& Kurnia, F. (2018). Analisis Kesuksesan Penerapan Sistem Administrasi Akademik Menggunakan Human Organization Technology Fit 
Model. Jurnal Ilmiah Rekayasa Dan Manajemen Sistem Informasi, 4(1), 36-41.

Nurani, D., Supriatin, S., Puspasari, M., \& Rachmawati, A. (2015). Aplikasi e-rapot berbasis web pada SMP N 1 Tempuran. Seminar NasionalTeknologiInformasidan Multimedia 2015, 1(1), 1-5.

Nurdyansyah, N., \& Fahyuni, E. (2016). Inovasi Model Pembelajaran Sesuai Kurikulum 2013. Bandung: Nizamia Learning Center.

Papilaya, J., Tuakora, P., \& Rijal, M. (2019). Compensation, transparency, and motivation effects on the performance of junior high school teachers in Western Seram, Indonesia. International Journal of Instruction, 12(3), 439-458.

Purnomo, Y. (2017). A scale for measuring teachers' mathematics-related beliefs: A Validity and reliability study. International Journal of Instruction, 10(2), 23-38.

Radityo, D. (2007). Pengujian Model DeLone and McLean Dalam Pengembangan Sistem Informasi Manajemen (Kajian Sebuah Kasus). In Simposium Nasional Akuntansi $X$ (pp. 1-25). Unhas Makassar.

Santosa, P. I. (2018). Metode Penelitian Kuantitatif Pengembangan Hipotesis dan Pengujiannya Menggunakan SmartPLS. Yogyakarta: Penerbit ANDI.

Soraya, I., Adawiyah, W. R., \& Sutrisna, E. (2019). Pengujian Model HOT Fit Pada Sistem Informasi Manajemen Obat di Instalasi Farmasi RSGMP UNSOED Purwokerto. Jurnal Ekonomi Bisnis Dan Akuntansi (JEBA), 21(1), 1-16.

Yuliasari, E. (2014). Analisis Faktor Determinan Penggunaan Sistem Aplikasi Pemeriksaan Laporan Keuangan dan Implikasinya. JNTETI, 03(2), 83-89.

Yusof, M. M., Paul, R. J., \& Stergioulas, L. K. (2006). Towards a framework for health information systems evaluation. In System Sciences, 2006. HICSS'06. Proceedings of the 39th Annual Hawaii International Conference on (Vol.5, pp. 95a-95a). IEEE.

Yusuf, A. M. (2016). Metode penelitian kuantitatif, kualitatif \& penelitian gabungan. Prenada Media. 